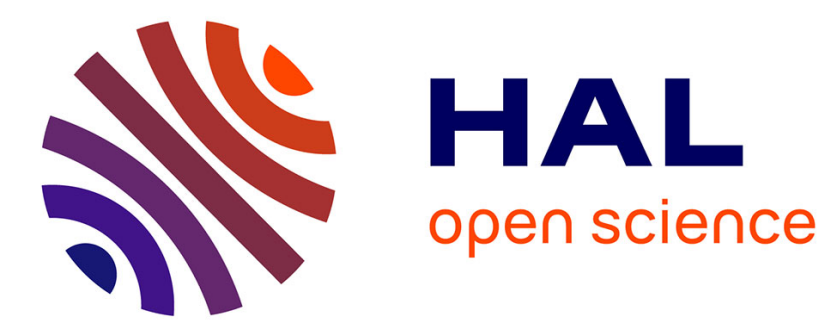

\title{
Environmental hazard assessment by the Ecoscore system to discriminate PAH-polluted soils
}

Christine Lors, Jean François Ponge, Denis Damidot

\section{To cite this version:}

Christine Lors, Jean François Ponge, Denis Damidot. Environmental hazard assessment by the Ecoscore system to discriminate PAH-polluted soils. Environmental Science and Pollution Research, 2018, 25 (27), pp.26747-26756. 10.1007/s11356-017-9906-4 . hal-01868669

\section{HAL Id: hal-01868669 \\ https://hal.science/hal-01868669}

Submitted on 5 Sep 2018

HAL is a multi-disciplinary open access archive for the deposit and dissemination of scientific research documents, whether they are published or not. The documents may come from teaching and research institutions in France or abroad, or from public or private research centers.
L'archive ouverte pluridisciplinaire HAL, est destinée au dépôt et à la diffusion de documents scientifiques de niveau recherche, publiés ou non, émanant des établissements d'enseignement et de recherche français ou étrangers, des laboratoires publics ou privés. 


\title{
Environmental hazard assessment by the Ecoscore System to discriminate PAH-polluted soils
}

\author{
Christine Lors $^{1,2} *$, Jean-François Ponge ${ }^{3}$, Denis Damidot ${ }^{1,2}$
}

\begin{abstract}
${ }^{1}$ IMT Lille Douai, Univ. Lille, EA 4515 - LGCgE - Laboratoire de Génie Civil et Géoenvironnement, département Génie Civil \& Environnemental, 941 rue Charles-Bourseul, 59508 Douai, France

${ }^{2}$ Université Lille Nord de France, 1bis rue Georges Lefèvre, 59044 Lille Cedex, France

${ }^{3}$ Muséum National d'Histoire Naturelle, CNRS UMR 7179, 4 Avenue du Petit Château, 91800 Brunoy, France
\end{abstract}

*Corresponding author: E-mail: christine.lors@imt-lille-douai.fr, Tel : +33327712674

\begin{abstract}
A bioassay battery-integrated index was applied to different soils sampled from a former coke factory, with the aim to evaluate the discriminating capacity of the Ecoscore System (ES) to assess the environmental hazard of PAH-polluted soils. Two soils from a former coke factory, polluted with polycyclic aromatic hydrocarbons (PAHs), were evaluated for their ecotoxicity to terrestrial and aquatic organisms and their genotoxicity. These soils have been already presented in a previous paper but data have been reanalysed for the present article in an endeavour to standardize the Ecoscore System. One soil was sampled in the untreated site and the second underwent a windrow treatment. While these soils had a similar total concentrations of US-EPA 16PAHs (around $3000 \mathrm{mg} \mathrm{kg}^{-1}$ ), different ecoscores were obtained when subjected to a set of solid- and liquid-phase bioassays measuring acute, chronic and genotoxic effects. The total PAH content of the soil is not a pertinent parameter to assess soil pollution hazards contrary to the Ecoscore System. ES is a robust method to classify soils according to their toxicity level. Four levels of toxicity have been defined: no (ecoscore $=0)$, weak $(0<$ ecoscore $\leq 33)$, moderate $(33<$ ecoscore $\leq 67)$, and strong toxicity $(67<$ ecoscore $\leq 100)$. The combination of chemical and toxicological data highlights the relationship between 3-ring PAHs and acute ecotoxicity. Conversely, chronic effects of water extracts on algal growth could be explained by high molecular weight PAHs, such as 5- and 6-ring PAHs.
\end{abstract}

Keywords: PAHs; Contaminated soils; Ecotoxicity; Solid bioassays; Liquid bioassays; Bioavailability; Ecoscores. 


\section{Introduction}

Industrial activities led to the discharge of a wide range of hazardous chemicals in soils. These pollutants include mostly hydrocarbon aromatic hydrocarbons (PAHs) and heavy metals. PAHs are a group of persistent hydrophobic organic pollutants which contains two or more fused aromatic rings (Cerniglia 1992). PAHs are mainly generated from the incomplete combustion and pyrolysis of organic materials (wood, coal, oil, petrol and plastics), coal liquefaction and gasification, creosote production, petroleum refining and other high-temperature industrial processes (Cerniglia 1992; Bispo et al. 1999). PAHs are a major environmental and health concern because of their potentially toxic, mutagenic and carcinogenic properties (White and Claxton 2004). The U.S. Environmental Protection Agency (US-EPA) has established that 7 compounds among 16 PAHs are potentially carcinogenic to humans [http://www.epa.gov/region5/cleanup/indianaharbor/pdfs/supplementalriskassessmentchapt6.pdf].

PAHs can adversely affect not only human health but also terrestrial and aquatic ecosystems. Hazard risk assessments of polluted soils are usually performed by chemical analysis to determine concentrations of target compounds. However, chemical analysis does not allow to identify all the compounds but only to quantify those which are analysed. Moreover, it does not provide information on the bioavailability of pollutants, neither on synergic or antagonistic phenomena between pollutants, nor on their effect on living organisms (Juvonen et al. 2000). In the case of PAHs that are hydrophobic organic pollutants, they may be adsorbed onto soil matrices and thus be less bioavailable (Semple et al. 2003). Soil properties, such as organic matter content and ageing, also play an important role in the bioavailability of PAHs (Chung and Alexander 2002; Riding et al. 2013). These parameters can significantly affect their fate in ecosystems and their impact on species and populations (Peijnenburg et al. 2002). Thus, chemical analysis needs to be complemented with an ecotoxicological approach allowing integrating the effects of all bioavailable contaminants (Fernandez et al. 2005; Leitgib et al. 2007). As a species sensitive to all environmental contaminants does not exist, a battery of bioassays involving organisms at different levels of biological organization and accounting for acute/chronic ecotoxicity and genotoxicity is recommended to evaluate environmental hazards of contaminated soils (Rila and Eisentraeger 2003; Fernandez et al. 2005).

Different approaches were performed to assess soil ecotoxicity: bioassays on whole soil using bacteria, earthworms, collembolans and plants (Lors et al. 2010), liquid bioassays applied on both water and organic extracts (Bispo et al. 1999) and combinations of both bioassays on whole soil and on soil water extracts (Mendoça and Picado 2002; Eom et al. 2007). Direct toxic effects on terrestrial organisms may reflect the ecotoxicological potential of contaminated soils (Fent 2003; Lors et al. 2010), whereas soil organic extracts may lead to an overestimation of the real bioavailability of organic pollutants (Alexander 1991). A combined approach using terrestrial and aquatic bioassays gave satisfactory results from the viewpoint of ecological relevance (Lors et al. 2011).

Different bioassay battery-integrated indexes were reported to characterize the ecotoxicological risk of contaminated sites, particularly contaminated sediments: a Test Battery integrated Index (TBI) is reported in the handbook of ISPRA (2011) and a Toxicity Classification System (TCS) in Persoone et al. (2003). These indexes were used to integrate the results of several tested bioassays. TCS is based on two values: a ranking in 5 acute hazard classes (no, slight, acute, high acute, very high acute hazards) and a weight score for each hazard class (0 to 3). TBI allows ranking five levels of ecotoxicological risk (not significant, low, medium, high, very high), which differ from those of TCS for the first three classes. The quality of sediments of Taranto seas (Mar Grande and Mar Piccolo) was evaluated by these two integrated systems from a battery of five test species representing different trophic levels (Prato et al. 2015). The results obtained showed a similarity between TCS and TBI for the high levels of ecotoxicological risk. Nevertheless, for the lower levels of toxicity, TCS gave a more severe assessment of risk, classifying sediment samples 
as high acute toxic whereas TBI indicated a low toxicity. In the present study, the Ecoscore System (ES, Lors et al. 2010) was applied to contaminated soils providing from historical industrial sites.

The first goal of this work is to demonstrate through two historical contaminated soils presenting a similar total concentration of PAHs that chemical analyses are not sufficient to evaluate the hazard of polluted soils and these analyses have to be complemented by ecotoxicological bioassays.

The second goal is to confirm the robustness of a method previously defined by Lors et al. (2011), in order to evaluate the environmental risk through the calculation of an ecoscore. It was thus applied in the present article to two polluted soils, in order to check its robustness. Additionally, the combination of chemical and toxicological data was used to bring some new insights on the ecotoxicity of different types of PAHs.

Data on the factory soils used for the present study have been already presented in Lors et al. (2011), but they have been reanalysed for the present article, in order to standardize the Ecoscore System (ES) for more user-friendly comparisons between soils. In order to allow a better appraisal of the interest of the ES method to ESPR readers and to facilitate comparison with similar studies, data obtained on the soils under study, as well as the methods we used to analyse them from a chemical and ecotoxicological point of view, will be presented in the foregoing chapters.

\section{Materials and methods}

As mentioned above, analytical and ecotoxicological data have been already presented in Lors et al. (2011). They have been briefly summarized below.

\section{Soil samples}

Experiments were carried out on two contaminated soils, named Soil A and Soil B, sampled from two historical industrial sites located in the North of France. The distillation of coal tar was the main activity on these sites, taking place from 1923 to 1987 and 1925 to 1973, respectively. Soil A was sampled in the untreated industrial site whereas Soil B underwent a windrow treatment for 18 months from October 1995 to June 1997. Despite bioremediation, this soil was still polluted with PAHs, with a total concentration still around that of Soil A.

Unpolluted soils were sampled in the two studied sites in uncontaminated areas. Chemical characteristics of these control soils, named Control A and Control B, are reported in Table 1. These soils were used as controls in the avoidance test and as a dilution matrix in solid-phase bioassays. The ecotoxicological characterization of control soils did not show any ecotoxicity. The procedure used for soil sampling has been described by Lors et al. (2010).

\section{Analytical data}

Soil water extraction was carried out according to ISO 21268-2 (2007). PAH-releasing capacity was expressed by the ratio between $\mathrm{PAH}$-concentration in water extract (per unit mass of soil for water extraction) and PAH-concentration in soil.

Soil $\mathrm{pH}_{\text {water }}$ was determined using a Consort $\mathrm{C} 83 \mathrm{pH}$-meter fitted with a glass electrode corrected for temperature. Total organic carbon concentration was obtained from total carbon and inorganic carbon contents, determined with a TOC-5000A Shimatzu ${ }^{\circledR}$ analyser, according to ISO 10694 (1995).

Concentrations of the 16 PAHs of the US-EPA list (Verschueren, 2001) were dosed in soil and water extracts according to ISO 13877 (1998). However, PAH concentration in water extracts did not include acenaphthylene. The 
extraction of PAHs from soil samples was carried out with the solvent extractor system Dionex ${ }^{\circledR}$ ASE 200 (Dionex Corporation $^{\circledR}$, Sunnyvale, CA). Concentrations of the 16 PAHs were dosed in the extracts by High Performance Liquid Chromatography (Waters ${ }^{\circledR}$ HPLC 2690, Milford, MS), coupled to a UV photodiode array detector (Waters ${ }^{\circledR}$ 996). The ratio between PAH concentration in water extract and PAH concentration in soil allowed determining the PAH water extraction capacity of the studied soils. All chemical analyses were done in triplicate.

The particle size distribution of soils was determined by separating soil samples into six fractions: > 2000, 2000$200,200-50,50-20,20-2$, and $<2 \mu \mathrm{m}$. The first three fractions were obtained by dry sieving using sieves between 50 and $200 \mu \mathrm{m}$. The smaller fractions $(<50 \mu \mathrm{m})$ were obtained by moist procedure, at first by sieving the soil under water through a $20 \mu \mathrm{m}$ sieve. The fraction retrieved on the sieve, corresponding to the fraction $20-50 \mu \mathrm{m}$, was dried to $20^{\circ} \mathrm{C}$. The suspension, corresponding to the fraction $<20 \mu \mathrm{m}$, was centrifuged to $1000 \mathrm{rpm}$ during $3.5 \mathrm{~min}$. The recovered fraction was dried at $30^{\circ} \mathrm{C}$.

\section{Ecotoxicological data}

Bioassays were performed to assess the direct toxicity of soils and soil water extracts to terrestrial and aquatic organisms, respectively. The set of bioassays included acute, chronic and genotoxicity effects, using organisms representative of a variety of trophic levels.

Toxicity end-points were the responses of test organisms to soils or water extracts in test media $(\%, \mathrm{w} / \mathrm{w})$. Results were calculated as concentrations producing no significant effect (NOEC), percent inhibition at the highest concentration of the tested sample or as concentrations decreasing the measured endpoint by $10 \%, 20 \%$ and $50 \%$ $\left[\mathrm{E}(\mathrm{L}) \mathrm{C}_{10}, \mathrm{E}(\mathrm{L}) \mathrm{C}_{20}\right.$ and $\mathrm{E}(\mathrm{L}) \mathrm{C}_{50}$, respectively] compared to controls. $\mathrm{E}(\mathrm{L}) \mathrm{C}_{\mathrm{x}}$ values were calculated following adjustment of data to a log-probit logistic model (Litchfield and Wilcoxon, 1949).

The toxicity of soils was evaluated by Lors et al. (2011) from nine bioassays tested on the basis of their best sensitivity to PAH pollution. This set of bioassays included both solid and liquid phases and addressed acute and chronic toxicities and genotoxicity: two rapid bioassays (Microtox ${ }^{\circledR}$ and springtail avoidance), a micronucleus test and three bioassays of a longer duration (algal growth, lettuce germination and springtail reproduction).

Bioassays applied directly on the soil included an acute phytotoxicity bioassay on Lactuca sativa (ISO 11269-2 2005). A chronic toxicity bioassay based on springtail (Folsomia candida) reproduction was conducted according to ISO 11267 (1999) modified by Martínez Aldaya et al. (2006). An avoidance test was conducted on Folsomia candida according to Martínez Aldaya et al. (2006) and Lors et al. (2006). Terrestrial toxicity bioassays were performed by using Control A and Control B as a dilution matrix for Soil A and Soil B respectively. The $\mathrm{pH}$ of both soils was around 8 and thus was compatible with requirements of test organisms.

The toxicity of water extracts to aquatic organisms was assessed through both acute and chronic effects. An acute ecotoxicity test was performed by measuring the inhibition of bioluminescence of the bacterium Vibrio fischeri according to ISO 11348-3 (1998). Chronic ecotoxicity was determined on the growth of the fresh water alga Pseudokirchneriella subcapitata according to ISO 8692 (2004). Each concentration was tested in six replicate microplates. The $\%$ inhibition of the population growth was determined for each concentration by comparison with the control.

The genotoxicity of water extracts was evaluated with the in vitro micronucleus assay applied on mouse lymphoma cells L5178Y according to the procedure described by Nesslany and Marzin (1999). The criteria for determining a genotoxic effect were a concentration-related increase in the number of micronucleated cells and a statistically significant increase over the spontaneous level in at least one treatment schedule. 


\section{Calculation of ecoscores}

Toxic effects were calculated as percentages of inhibition at a given concentration or as $\mathrm{LE}_{\mathrm{Cx}}$ values. Percent inhibition was determined with respect to the control soil. $\mathrm{LE}_{\mathrm{Cx}}$ values were calculated following adjustment of data to a logprobit logistic model (Litchfield and Wilcoxon 1949). NOEC was the highest concentration tested that did not significantly differ from control with a type I error $(\alpha)$ of $5 \%$. LOEC was not used and was replaced by $\mathrm{EC}_{10}$ or $\mathrm{LC}_{10}$. Toxicity values were also expressed in Toxic Units (TU), using the formula $\mathrm{TU}=100 / \mathrm{EC}$ (or LC) $)_{50}$.

From five ecotoxicological parameters, $\mathrm{E}(\mathrm{L}) \mathrm{C}_{50}, \mathrm{E}(\mathrm{L}) \mathrm{C}_{20}, \mathrm{E}(\mathrm{L}) \mathrm{C}_{10}, \mathrm{NOEC}, \%$ inhibition, scores were calculated by assigning to each endpoint value a score between 0 and 100 as a function of its intensity. It was noticed that the scale of the scores was modified compared to that defined by Lors et al. $(2010)(0<$ score $<3)$, in order to normalize to 100 the maximum effect.

For $\mathrm{E}(\mathrm{L}) \mathrm{C}_{50}, \mathrm{E}(\mathrm{L}) \mathrm{C}_{20}, \mathrm{E}(\mathrm{L}) \mathrm{C}_{10}$, NOEC, the following scale ( $\mathrm{x}$ = endpoint value) was used:

$$
\begin{aligned}
& \circ \quad 0=\text { no effect }(x>100) \\
& \circ \quad 33=\text { weak effect }(50<x \leq 100) \\
& \circ \quad 67=\text { medium effect }(20<x \leq 50) \\
& \circ \quad 100=\text { strong effect }(x \leq 20)
\end{aligned}
$$

For $\%$ inhibition, the following scale was used:

$$
\begin{array}{ll}
\circ & 0=\text { no effect }(x \leq 5) \\
\circ & 33=\text { weak effect }(5<x \leq 20) \\
\circ & 67=\text { medium effect }(20<x \leq 60) \\
\circ & 100=\text { strong effect }(x>60)
\end{array}
$$

For each bioassay, the five scores were summed up and divided by the number of endpoints, in order to calculate a bioassay-score. Bioassay-score values allowed evaluating the sensitivity of the different bioassays.

An ecoscore was calculated for each soil by averaging the values of the different bioassay-scores. The following scale was used to define the environmental risk of PAH-polluted soils and classify soils in function of the intensity of toxicity:

\footnotetext{
$\circ$ no toxicity $($ ecoscore $=0)$

$\circ$ weak toxicity $(0<$ ecoscore $\leq 33)$

$\circ \quad$ moderate toxicity $(33<$ ecoscore $\leq 67)$

$\circ \quad$ strong toxicity $(67<$ ecoscore $\leq 100)$
}

\section{Results and discussion}

\section{Chemical and toxicological characteristics of the soils}

The particle size distribution of the studied soils was reported on Figure 1. Soil B was composed almost exclusively of particles between 2000 and $50 \mu \mathrm{m}(79 \%)$, corresponding to sand. Within this class, the fraction 2000-200 $\mu \mathrm{m}$ (coarse sand) was dominant (56\%) compared with fine sand $(23 \%)$. Silt and clay fractions were present in very small proportion, $3.3 \%$ and $0.2 \%$, respectively. The particle size distribution of soil A was comparable to that of soil B: the sand fraction was dominant (86\%), with a similar dominance of coarse sand $(68 \%)$. Finer textural classes were distributed with proportions almost similar to those of soil B: $4.4 \%$ and $0.3 \%$ for silt and clay fractions, respectively. 
Soil A was mainly contaminated with organic compounds. This soil was heavily polluted with PAHs, with a global content of the 16PAHs of the US-EPA list around $3 \mathrm{~g} \mathrm{~kg}^{-1}$ dry soil, mainly represented by 2-, 3- and 4-ring compounds (Table 1). Three-ring PAHs were the most represented (44\% of $\sum 16 \mathrm{PAHs}-1279.2 \mathrm{mg} \mathrm{kg}^{-1}$ dry soil), followed by 2- and 4-ring compounds ( 28 and $20 \%, 594.2$ and $808.9 \mathrm{mg} \mathrm{kg}^{-1}$ dry soil, respectively) (Fig. 2). Five- and 6-ring PAHs were hardly present in this soil (5 and $2 \%, 149.2$ and $63.2 \mathrm{mg} \mathrm{kg}^{-1}$ dry soil, respectively).

Soil B was highly polluted with PAHs, to a level similar to Soil A ( $\left.\sum 16 \mathrm{PAHs}=3687.2 \mathrm{mg} \mathrm{kg}^{-1}\right)$ (Table 1$)$. However, the PAH distribution pattern was different from Soil A. Four-ring PAHs were the most represented (50\% of $\sum$ 16PAHs - $1726.9 \mathrm{mg} \mathrm{kg}^{-1}$ dry soil) followed by 5- and 6-rings PAHs (22 and $11 \%-796.1$ and $389.8 \mathrm{mg} \mathrm{kg}^{-1} \mathrm{dry}$ soil) (Fig. 2). Contrary to soil A, 3-ring PAH content was lower, 623.5 against $1279.2 \mathrm{mg} \mathrm{kg}^{-1}$ dry soil for Soil A. This difference of distribution is probably the consequence of the partial biodegradation of PAHs during biotreatment that was more efficient to decrease 2- and 3-rings PAHs, as expected (Lors et al. 2010). Thus, the concentrations of 4-, 5-, and 6-rings PAHs were higher for Soil B contrary to 2- and 3-rings PAHs.

A higher amount of organic carbon was also detected in Soil B (442 $\mathrm{g} \mathrm{kg}^{-1}$ dry soil) compared to Soil A (90 g $\mathrm{kg}^{-1}$ dry soil). This difference could be explained by the addition of compost during the windrow treatment of Soil B. This can be confirmed by the high $\mathrm{N}$ and $\mathrm{P}$ amounts detected in this soil, amounting to 5600 and $1900 \mathrm{mg} \mathrm{kg}^{-1}$, respectively (Table 1). As the dominant fraction of the two soils was coarse sand, it is possible that the organic part could be contained in this fraction.

Soil A induced a strong inhibition of lettuce germination. At the highest dose tested, lettuce germination was inhibited to about $70.9 \%$ (Table 2) and the bioassay-score was to 93 (Table 4). Conversely, Soil B showed a significantly lower phytotoxicity towards lettuce germination with an inhibition of $21.4 \%$ (Table 3) and a bioassayscore of only 47 (Table 4).

The Folsomia population reproduction bioassay showed that Soil A had a high chronic ecotoxicity, with an inhibition rate of $100 \%$ and a bioassay-score of 100 (Tables 2 and 4) whereas Soil B did not elicit any response by Folsomia candida populations (Table 3). For Soil B, the behavioural test seemed to be more sensitive than ecotoxicity tests since it allowed to detect a significant repellence (bioassay-score $=67$, Table 4). Nevertheless, the repellence level was lower than that of Soil A (bioassay-score $=100$, Table 4).

Soil A presented a strong ecotoxicity towards terrestrial organisms whereas the ecotoxicity of Soil B was moderate. Ecoscores of Soil A and Soil B, obtained with this battery of bioassays, were 97.7 and 38.0, respectively (Table 4).

The fact that these two soils showed the same high level of organic pollution whereas their ecotoxicity assessed by solid bioassays was different demonstrates that the global content of PAHs is not the pertinent parameter to evaluate soil pollution hazards. Conversely, the distribution of PAHs gave a better picture of soil pollution and it can explain partly the ecotoxic responses obtained. In fact, the high ecotoxicity of Soil A to terrestrial organisms is probably related to its high concentration in 3-ring PAHs. Indeed, a positive and significant relationship between ecoscores pooled over the three solid bioassays and the concentration of 3-ring PAHs was found by Lors et al. (2010). Soil A exhibited a high ecotoxicity on organisms tested (plants and Collembola), with bioassay-scores of 93, 100 and 100 to Lactuca germination, Folsomia population growth and Folsomia avoidance, respectively (Table 4). These results confirmed those of Svrdrup et al. (2002) who showed that 2-, 3- and 4-rings PAHs significantly affected the survival and reproduction of Collembola and earthworms while PAHs with a high lipophily did not. The same results were obtained by Čvančarová et al. (2013) who indicated a better sensitivity of the earthworm Eisenia fetida to PAHs with 34 rings aromatic rings. The growth inhibition of this organism is linked to the accumulation of PAHs in earthworm tissues. Although Soil A contains 4-ring PAHs at a lesser concentration than 3-ring PAHs, 4-ring PAHs also contribute 
to the ecotoxicological effects measured.

Moreover, Soil B exhibited a weak acute ecotoxicity towards lettuce and no chronic ecotoxicity towards Collembola. Comparatively to Soil A, Soil B contains lesser concentrations of 3-ring PAHs but higher concentrations of 4-ring PAHs. If we consider that 3- and 4-rings PAHs were responsible for the impact of PAHs on Collembola and earthworms (Eom et al. 2007; Sverdrup et al. 2002), the results might indicate that 3- and 4-rings PAHs in Soil B were less bioavailable to the exposed organisms. Indeed, Soil B had 50\% less 3-ring PAHs and these compounds were very

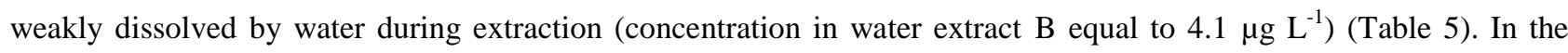
same way, although the content of 4-ring PAHs was 50\% higher, a weak fraction was dissolved in water after extraction (concentration in water extract $\mathrm{B}$ equal to $13.7 \mu \mathrm{g} \mathrm{L}^{-1}$ ). As a consequence, these compounds should be sequestered in other insoluble organic compounds in this soil.

Although any effect was detected on Folsomia candida population growth, Soil B was repellent to the same organism at a lower level than Soil A (Bioassay-scores of 100 and 67 for Soils A and B, respectively - Table 4), confirming the better sensitivity of behavioural tests (avoidance by Folsomia) compared to ecotoxicity tests.

\section{Chemical and toxicological characteristics of water extracts}

The water extraction of soils gives an information on the soluble fraction and thus on the fraction directly accessible to organisms through diffusion. Aqueous leaching tests showed that Soil A had a strong capacity to release PAHs. In fact, the ratio PAH concentration in water extract / soil was equal to $2.210^{-3}$. Water extract A mainly contained 3-ring PAHs (82\% of $\sum 16 \mathrm{PAHs}-531.1 \mu \mathrm{g} \mathrm{L}^{-1}$ ) (Table 5). Their high concentration in solution was linked to their amount in Soil A (1279.2 $\mathrm{mg} \mathrm{kg}^{-1}$ dry soil) and the higher solubility of PAHs of lower molecular weight (Table 1). Naphthalene was present at a small concentration $\left(0.2 \mu \mathrm{g} \mathrm{L}^{-1}\right)$ despite its high amount in Soil A. This was probably due to its volatilization during water extraction, given its high vapour tensile strength (37 $\mathrm{Pa})$.

The leaching rate of PAHs decreased with the number of rings (Fig. 3). PAH concentrations in water extracts were correlated to the water-solubility of these pollutants. More soluble PAHs, such as acenaphthene, fluorene and phenanthrene, were found at the highest concentrations in Water extract A (Table 5). Conversely, 4-ring PAHs were present in a lesser proportion (15\% of $\sum 16 \mathrm{PAHs}-96.9 \mu \mathrm{g} \mathrm{L}^{-1}$ ), whereas 5- and 6- rings PAHs were not significantly represented in water extract $\mathrm{A}\left(1.8 \%\right.$ and $0.8 \%-11.3$ and $5.3 \mu \mathrm{g} \mathrm{L}^{-1}$, respectively) (Table 5).

Soil B had a low capacity for PAHs remobilization: this soil released 10 times lower amounts of PAHs than Soil A $\left(1.610^{-4}\right)$. Five- and 6-rings PAHs were the most represented (respectively 37 and $30 \%$ of $\sum 16$ PAHs -21.4 and $17.5 \mu \mathrm{g} \mathrm{L}^{-1}$ ) (Table 5). Among 5-ring PAHs, benzo(b)anthracene and benzo(a)pyrene were the major compounds in water extract B. Water extract B also contained 4-ring PAHs in a lesser proportion $\left(23.9 \%\right.$ of $\left.\sum 16 \mathrm{PAHs}-13.7 \mu \mathrm{g} \mathrm{\textrm {L } ^ { - 1 }}\right)$. Three-ring PAHs were also hardly released and thus their concentrations were about 100 times less than Water extract A. The windrow treatment applied to this soil was efficient because it removed low molecular weight PAHs and remaining PAHs were the compounds most recalcitrant to microbial degradation. PAH degradation may also be limited by the slow desorption of PAHs from the soil matrix (Juhasz et al. 2005). In fact, Soil B contains essentially 4-, 5- and 6-ring PAHs, which were characterized by a weak water-solubility and a high lipophily.

Water extract A exhibited a strong acute ecotoxicity to Vibrio fischeri (bioassay-score = 100) $($ Table 4). Conversely, Water extract B did not show any acute ecotoxicity with the bioassay tested (bioassay-score $=0)($ Table 4). These results seemed to be linked to the 3-ring PAH content of these water extracts: high amount in water extract A ( $\Sigma$ 3-ring PAHs $\left.=531.1 \mu \mathrm{g} \mathrm{L}^{-1}\right)$ and small amount in water extract B $\left(\left(\sum\right.\right.$ 3-ring PAHs $\left.=4.1 \mu \mathrm{g} \mathrm{L}{ }^{-1}\right)($ Table 5). This 
confirms the strong correlation between acute ecotoxicity and 3-ring PAHs observed by Lors et al. (2011), which is linked to their higher water solubility compared to PAHs of higher molecular weight (Bispo et al., 1999).

However, the effects of Water extracts A and B on algal growth were comparable on the basis of ecoscores. Water extracts A and B showed a high chronic response towards Pseudokirchneriella subcapitata (bioassay-scores of 80 for both water extracts) (Table 4). These results indicate that both soils had a potential impact to aquatic fauna in the long term and that ecotoxicological effects were due to 5- and 6-rings PAHs, although these were present in lower contents in both water extracts (Fig. 3). Nevertheless, the concentration in solution of 5- and 6-rings PAHs was above their hydrosolubility level (Table 5). The ratio between the concentration of each PAH in water extract and its watersolubility was higher than 1 for all 5- and 6-rings PAHs to the exception of benzo[g,h,i]perylene. This suggests that these high molecular-weight PAHs were associated with other compounds, such as suspended organic matter or were in colloidal form, making them bioavailable to aquatic organisms. Although it had been biotreated, Soil B contained a pool of PAHs that were potentially leachable. The battery must include bioassays taking into account different effects, acute, chronic toxicity and behavioural endpoints, in order to prevent potential hazards for ecosystems in the long term (Prato et al. 2015).

The micronucleus test applied to mouse lymphoma cells showed a high genotoxicity only without S9 activator (bioassay-score $=80$ ) for Water extract $\mathrm{A}$, indicating the presence of directly genotoxic compounds in this water extract. Conversely, not any genotoxic effect was observed for Water extract B. The fact that Water extract A is genotoxic only without S9 activator suggests that its genotoxicity response is not due to PAHs but certainly to other compounds present in this water extract. In fact, PAHs are known to be activated into genotoxic metabolites by S9 rat liver enzymes (Otto et al. 1991; IARC 2010). The ecotoxicological approach gives a global response and takes into account all potentially toxic compounds and not only those that have been determined by chemical analysis.

\section{Comparison of ecoscores of soils and soil water extracts}

The comparison of averaged ecoscores for solid and liquid phase bioassays showed that Soil A was classified as strongly toxic by both types of bioassays. Ecoscores were to 97.7 and 86.7 for solid and liquid phase bioassays, respectively. Conversely, Soil B, which was at the limit between weak and moderate effects, appeared weakly toxic by liquid phase bioassays (ecoscore $=26.7$ ) and moderately toxic by solid phase bioassays (ecoscore $=38.0$ ). This was due to a lower sensitivity of liquid phase bioassays compared to that of solid phase bioassays as showed by Lors et al. (2011), an observation already made on plant growth tests by Ferrari et al. (1999). Chemical and ecotoxicological analyses of water extracts allowed us to know which water-soluble fraction was directly accessible to organisms. The water extract was complementary to the bulk soil in the procedure of hazard assessment. The weak toxicity of soil B compared to the strong toxicity of soil A was also confirmed by the calculation of ecoscores using both solid and liquid phase bioassays: ecoscores were 32.3 and 92.2 , respectively (Table 4).

Our method of selection based on ecoscores was comparable to the Test Battery integrated Index (TBI). However, TBI has an additional class, named 'very high' and this level corresponds to the 'high level' in the Ecoscore System (ES). Moreover, the high level in TBI corresponds to the medium level in ES. TBI thus overestimates the ecotoxicological risk in comparison with ES. In fact, Manzo et al. (2014) showed that TBI did not allow highlighting differences among the sites studied and showed a general high ecotoxicological risk. Nevertheless, while overestimating the ecotoxicological risk compare to ES, similar discriminating capacity could be obtained when using TBI ecotoxicological risk levels: according to TBI Soils A and B are classed very highly and highly toxic, respectively. 


\section{Conclusions}

Two coke factory soils contaminated with similar total PAH concentration were characterized by chemical and ecotoxicological approaches applied to the whole soil and to the water extract. The battery of bioassays including solid and liquid-bioassays took into account acute, chronic and genotoxic effects. The chemical analysis of soil water extracts gave information on the soluble fraction corresponding to the pollutants directly accessible to organisms. Nevertheless, it was necessary to complete chemical analyses by ecotoxicity bioassays which proved to be more sensitive indicators of soil quality. The Ecoscore System (ES), based on ecoscores calculated from a battery of liquid and solid phase bioassays, proved to be a robust method which allowed us to evaluate the sensitivity of bioassays and to classify soils according to their toxicity level and particularly to differentiate the two studied soils despite their similar total concentration of PAHs. The total PAH content of soil was not the more pertinent parameter to assess the hazard of polluted soils, contrary to the distribution of PAHs: the combination of chemical and toxicological approaches highlighted the relationship between acute ecotoxicity and 3-ring PAHs (most soluble compounds). In the same way, the chronic effect of both water extracts on algal growth can be explained by high molecular weight PAHs, such as 5 and 6-ring PAHs. A procedure involving the battery of bioassays proposed (two rapid bioassays, Microtox and springtail avoidance, a micronucleus test and three bioassays of a longer duration, algal growth, lettuce germination and springtail reproduction) and the calculation of resulting ecoscores provides a discriminant assessment of soils contaminated by PAHs which could be implemented in bioremediation programs. It offers the advantage of allowing an easy comparison of various soils on the base of a wide array of acute and chronic solid- and liquid-phase toxicity tests, without resorting to complex data analyses. The proposed Ecoscore System proved effective to discriminate between weak and strong toxicity hazard of the two studied soils, despite their similar total PAH concentration.

\section{Acknowledgements}

The present study was performed with a financial support from the ADEME (Agence de l'Environnement et de la Maîtrise de l'Énergie, France), which is greatly acknowledged. We thank Total (France) and Charbonnages de France (France) to put industrial sites at our disposal.

\section{References}

Alexander M (1991) Research needs in bioremediation. Environ Sci Technol 25: 1972-7973.

Bispo A, Jourdain MJ, Jauzein M (1999) Toxicity and genotoxicity of industrial soils polluted by polycyclic aromatic hydrocarbons (PAHs). Org Geochem 30: 947-952.

Cerniglia CE (1992) Biodegradation of polycyclic aromatic hydrocarbons. Biodegradation 3: 351-368.

Chung N, Alexander M (2002) Effect of soil properties on bioavailability and extractability of phenanthrene and atrazine sequestered in soil. Chemosphere 48: 109-115.

Čvančarová M, Křesinová Z, Cajthaml T (2013) Influence of the bioaccessible fraction of polycyclic aromatic hydrocarbons on the ecotoxicity of historically contaminated soils. J Hazard Mater 254-255: 116-124.

Eom IC, Rast C, Veber AM, Vasseur P (2007) Ecotoxicity of a polycyclic aromatic hydrocarbon (PAH)-contaminated soil. Ecotoxicol Environ Saf 67:190-205.

Fent K (2003) Ecotoxicological problems associated with contaminated sites. Toxicology Letters 140-141: 353-365. 
Fernandez MD, Cagigal E, Vega MM, Urzelai A, Babin M, Pro J, Tarazona JV (2005) Ecological risk assessment of contaminated soils through direct toxicity assessment. Ecotoxicol Environ Saf 62: 174-184.

Ferrari B, Radetski CM, Veber AM, Ferard JF (1999) Ecotoxicological assessment of solid wastes: a combined liquidand solid-phase testing approach using a battery of bioassays and biomarkers. Environ Toxicol Chem 18: 1195-1202. Doi:10.1002/etc.5620180618.

IARC (2010) IARC monographs on the evaluation of carcinogenic risks to Humans. Some non-heterocyclic polycyclic aromatic hydrocarbons and some related exposures. Working Group on the Evaluation of Carcinogenic Risks to Humans. Vol 92. https://monographs.iarc.fr/ENG/Monographs/vo192/mono92.pdf.

ISO 10694 (1995) Soil Quality - Determination of organic carbon and total carbon after dry combustion (Elementary analysis). International Organization for Standardization, Geneva.

ISO 13877 (1998) Soil Quality - Determination of polynuclear aromatic hydrocarbons, method using high-performance liquid chromatography. International Organization for Standardization, Geneva.

ISO 11348-3 (1998) Water Quality - Determination of inhibitory effects of water samples on the light emission of Vibrio fischeri (luminescent bacteria test). Part 3. Method with freeze-dried bacteria. International Organization for Standardization, Geneva.

ISO 11267 (1999) Soil Quality - Inhibition of reproduction of Collembola (Folsomia candida) by soil pollutants. International Organization for Standardization, Geneva.

ISO 8692 (2004) Water Quality - Freshwater algal growth inhibition test with unicellular green algae. International Organization for Standardization, Geneva.

ISO 11269-2 (2005) Soil Quality - Determination of the pollutants effects on soil flora. Part 2. Effects of chemicals on the emergence and growth of higher plants. International Organization for Standardization, Geneva.

ISO 21268-2 (2007) Soil Quality - Leaching procedures for subsequent chemical and ecotoxicological testing of soil and soil materials. Part 2. Batch test using a liquid to solid ratio of $10 \mathrm{~L} / \mathrm{kg}$ dry matter. International Organization for Standardization, Geneva.

ISPRA (2011) Batterie di saggi ecotossicologici per sedimenti di acque salate e salmastre. Manuali e linee guida 67/2011. Istituto Superiore per la Protezione e la Ricerca Ambientale, Rome.

Juhasz AL, Waller N, Lease C, Bentham R, Stewart R (2005) Pilot scale bioremediation of creosote-contaminated soil: efficacy of enhanced natural attenuation and bioaugmentation strategies. Bioremediat J 9: 139-154.

Juvonen R, Martikainen E, Schultz E, Joutti A, Ahtiainen J, Lehtokari M (2000) A battery of toxicity tests as indicators of decontamination in composting oily waste. Ecotoxicol Environ Saf 47: 156-166.

Leitgib L, Kalman J, Gruiz K (2007) Comparison of bioassays by testing whole soil and their water extract from contaminated sites. Chemosphere 66: 428-434.

Litchfield JT, Wilcoxon F (1949) A simplified method of evaluating dose-effect experiments. J Pharmacol Exp Ther 96: 99-113.

Lors C, Martínez Aldaya M, Salmon S, Ponge JF (2006) Use of an avoidance test for the assessment of microbial degradation of PAHs. Soil Biol Biochem 38: 2199-2204.

Lors C, Ponge JF, Martínez Aldaya M, Damidot D (2010) Comparison of solid-phase bioassays and ecoscores to evaluate the toxicity of contaminated soils. Environ Pollut 158: 2640-2647.

Lors C, Ponge JF, Martínez Aldaya M, Damidot D (2011) Comparison of solid and liquid-phase bioassays using ecoscores to assess contaminated soils. Environ Pollut 159: 2974-2981.

Manzo S, Schiavo S, Aleksi P, Tabaku A (2014) Application of a toxicity test battery integrated index for a first screening of the ecotoxicological threat posed by ports and harbors in the southern Adriatic Sea (Italy). 
Environ Monit Assess 186: 7127-7139.

Martínez Aldaya M, Lors C, Salmon S, Ponge JP (2006) Avoidance bio-assays may help to test the ecological significance of soil pollution. Environ Pollut 140: 173-180.

Mendonça E, Picado A (2002) Ecotoxicological monitoring of remediation in a coke oven soil. Environ Toxicol 17: 74-79.

Nesslany F, Marzin D (1999) A micromethod for in vitro micronucleus assay, Mutagenesis 14: 403-410.

Otto S, Marcus C, Pidgeon C, Jefcoate C (1991) A novel adrenocorticotropin\&inducible cytochrome P450 from rat adrenal microsomes catalyzes polycyclic aromatic hydrocarbon metabolism. Endocrinology 129: 970-982.

Peijnenburg W, Sneller E, Sijm D, Ljizen J, Traas T, Verbruggen E (2002) Implementation of bioavailability in standard setting and risk assessment. J. Soils Sediments 2: 169-173.

Persoone G, Marsalek B, Blinova I, Törökne A, Zarina D, Manusadzianas L, Nalecz-Jawecki G, Tofan L, Stepanova N, Tothova L, Kolar B (2003) A practical and user-friendly toxicity classification system with microbiotests for natural waters and wastewaters. Environ Toxicol 18: 395-402.

Prato E, Parlapiano I, Biandolino F (2015) Ecotoxicological evaluation of sediments by battery bioassays: application and comparison of two integrated classification systems. Chem Ecol 31: 661-678.

Riding MJ, Doick KJ, Martin FL, Jones KC, Semple KT (2013) Chemical measures of bioavailability/bioaccessibility of PAHs in soil: fundamentals to application. J Hazard Mater 261: 687-700.

Rila JP, Eisentraeger A (2003) Application of bioassays for risk characterization and remediation control of soils polluted with nitroaromatics and PAHs. Water Air Soil Pollut 148: 223-242.

Semple KT, Morriss AWJ, Paton GI (2003) Bioavailability of hydrophobic organic contaminants in soils: fundamental concepts and techniques for analysis. Eur J Soil Sci 54: 809-818.

Sverdrup LE, Nielsen T, Krogh PH (2002) Soil ecotoxicity of polycyclic aromatic hydrocarbons in relation to soil sorption, lipophilicity, and water solubility. Environ Sci Technol 36: 2429-2435.

Verschueren K (2001) Handbook of environmental data on organic chemicals, 4th edn. Wiley, New York.

White PA, Claxton LD (2004) Mutagens in contaminated soil: a review. Mutat Res 567: 227-345. 


\section{Figure captions}

Fig. 1 Distribution of soil textural fractions (in mass \%) for each studied soil.

Fig. 2 Concentrations of 2-6 ring PAHs in the two studied soils. Values are means of three replicate dosages, with S.E. as error bars

Fig. 3 Ratio of PAH concentration in water extract to concentration in soil (expressed in \%) for the two studied soils. 
Table 1 Concentrations of PAHs in soils A and B and in their control soils (expressed in $\mathrm{mg} \mathrm{kg}^{-1}$ dry soil \pm SE) and concentrations of total organic carbon, total organic nitrogen, total phosphorus in soils A and B (expressed in $\mathrm{mg} \mathrm{kg}^{-1}$ dry soil \pm SE).

\begin{tabular}{|c|c|c|c|c|c|}
\hline & No. of rings & Soil A & Soil B & Control A & Control B \\
\hline Naphthalene & 2 & $594.2 \pm 13.8$ & $150.9 \pm 10.6$ & $0.13 \pm 0.01$ & $0.41 \pm 0.01$ \\
\hline Acenaphthylene & 3 & $3.1 \pm 0.1$ & $23.5 \pm 1.1$ & $0.04 \pm 0.001$ & $0.01 \pm 0.00$ \\
\hline Acenaphthene & 3 & $217.4 \pm 1.2$ & $2.0 \pm 0.1$ & $0.10 \pm 0.11$ & $0.01 \pm 0.00$ \\
\hline Fluorene & 3 & $226.8 \pm 2.8$ & $83.1 \pm 3.7$ & $0.02 \pm 0.001$ & $0.06 \pm 0.00$ \\
\hline Phenanthrene & 3 & $629.3 \pm 4.2$ & $308.2 \pm 17.7$ & $0.08 \pm 0.01$ & $1.01 \pm 0.03$ \\
\hline Anthracene & 3 & $202.5 \pm 31.7$ & $206.7 \pm 7.0$ & $0.01 \pm 0.00$ & $0.14 \pm 0.01$ \\
\hline Fluoranthene & 4 & $414.3 \pm 1.2$ & $625.2 \pm 30.7$ & $0.16 \pm 0.03$ & $2.01 \pm 0.05$ \\
\hline Pyrene & 4 & $233.4 \pm 0.4$ & $299.4 \pm 10.9$ & $0.13 \pm 0.01$ & $0.55 \pm 0.04$ \\
\hline Benzo[a]anthracene & 4 & $85.7 \pm 0.9$ & $391.9 \pm 13.1$ & $0.08 \pm 0.00$ & $0.37 \pm 0.03$ \\
\hline Chrysene & 4 & $75.4 \pm 0.9$ & $410.4 \pm 8.1$ & $0.08 \pm 0.01$ & $0.70 \pm 0.02$ \\
\hline Benzo[b]anthracene & 5 & $56.2 \pm 0.3$ & $210.8 \pm 5.8$ & $0.02 \pm 0.001$ & $1.13 \pm 0.25$ \\
\hline Benzo[k]fluoranthene & 5 & $25.8 \pm 0.3$ & $161.9 \pm 2.6$ & $0.02 \pm 0.001$ & $0.25 \pm 0.00$ \\
\hline Benzo[a]pyrene & 5 & $60.4 \pm 6.7$ & $364.1 \pm 2.9$ & $0.03 \pm 0.001$ & $0.92 \pm 0.17$ \\
\hline Dibenzo[ah]anthracene & 5 & $6.9 \pm 0.2$ & $59.3 \pm 0.3$ & $0.02 \pm 0.001$ & $0.09 \pm 0.00$ \\
\hline Benzo[ghi]perylene & & $32.5 \pm 1.0$ & $196.1 \pm 6.5$ & $0.10 \pm 0.05$ & $0.47 \pm 0.01$ \\
\hline Indeno $[123-c d]$ pyrene & & $30.8 \pm 0.3$ & $193.7 \pm 1.6$ & $0.10 \pm 0.05$ & $0.42 \pm 0.02$ \\
\hline 2-ring PAH & & $594.2 \pm 8.0$ & $150.9 \pm 6.1$ & $0.13 \pm 0.01$ & $0.41 \pm 0.01$ \\
\hline 3-ring PAHs & & $1279.2 \pm 20.3$ & $623.5 \pm 17.1$ & $0.26 \pm 0.12$ & $1.23 \pm 0.05$ \\
\hline 4-ring PAHs & & $808.9 \pm 1.0$ & $1726.9 \pm 36.2$ & $0.44 \pm 0.04$ & $3.63 \pm 0.14$ \\
\hline 5-ring PAHs & & $149.2 \pm 3.7$ & $796.1 \pm 6.7$ & $0.09 \pm 0.003$ & $2.40 \pm 0.43$ \\
\hline 6-ring PAHs & & $63.2 \pm 0.4$ & $389.8 \pm 4.6$ & $0.19 \pm 0.10$ & $0.88 \pm 0.02$ \\
\hline$\sum 16$ PAHs & & $2894.8 \pm 38.1$ & $3687.2 \pm 48.8$ & $1.10 \pm 0.70$ & $8.56 \pm 0.65$ \\
\hline Total organic carbon & & 90000 & 442000 & - & - \\
\hline Total organic nitrogen & & 1700 & 5600 & - & - \\
\hline Total phosphorus & & 620 & 1900 & - & - \\
\hline
\end{tabular}

Values are means of three replicate measures. Data from Lors et al. (2011) 
Table 2 Ecotoxicological characteristics of Soil A according to a restricted battery of solid and liquid bioassays

\begin{tabular}{|c|c|c|c|c|c|c|}
\hline & $\begin{array}{c}\mathrm{EC}_{50} \\
\left(\mathrm{g.100} \mathrm{g}^{-1}\right)\end{array}$ & $\begin{array}{c}\text { TU } \\
100 / \mathrm{EC}_{50}\end{array}$ & $\begin{array}{c}\mathbf{E C}_{20} \\
\left(\mathrm{g.100} \mathrm{g}^{-1}\right)\end{array}$ & $\begin{array}{c}\mathrm{EC}_{10} \\
\left(\mathrm{g.100} \mathrm{g}^{-1}\right)\end{array}$ & $\begin{array}{c}\text { NOEC } \\
\left(\mathrm{g} .100 \mathrm{~g}^{-1}\right)\end{array}$ & $\begin{array}{c}\text { Inhibition } \\
(\%)\end{array}$ \\
\hline Lactuca germination & $\begin{array}{c}21.3 \\
(15.5-29.3)\end{array}$ & 4.5 & $\begin{array}{c}3.5 \\
(1.9-6.5)\end{array}$ & $\begin{array}{c}1.4 \\
(0.6-3.4)\end{array}$ & $<5$ & 70.9 \\
\hline $\begin{array}{c}\text { Folsomia population } \\
\text { growth }\end{array}$ & $\begin{array}{r}2.2 \\
\text { N/A }\end{array}$ & 45.5 & $\begin{array}{r}2.1 \\
\text { N/A }\end{array}$ & $\begin{array}{r}1.9 \\
\text { N/A }\end{array}$ & 1 & 100 \\
\hline Folsomia avoidance & $\begin{array}{c}0.8 \\
(0.6-1)\end{array}$ & 129 & $\begin{array}{c}0.3 \\
(0.2-0.4)\end{array}$ & $\begin{array}{c}0.042 \\
(0.008-0.205)\end{array}$ & $<0.35$ & 100 \\
\hline $\operatorname{Microtox}^{\circledR}$ test & $\begin{array}{c}8.1 \\
(6.4-10.1)\end{array}$ & 12.4 & $\begin{array}{c}1.5 \\
(0.9-2.3)\end{array}$ & $\begin{array}{c}0.6 \\
(0.3-1.1)\end{array}$ & $<2.5$ & 89.1 \\
\hline Algal growth & $\begin{array}{c}42.9 \\
(40.4-45.6)\end{array}$ & 2.3 & $\begin{array}{c}28.0 \\
(25.7-30.5)\end{array}$ & $\begin{array}{c}22.4 \\
(20.0-25.0)\end{array}$ & $<20$ & 93.4 \\
\hline Micronucleus test (-S9) & $\begin{array}{c}16.1 \\
(13.4-19.3)\end{array}$ & 6.2 & $\begin{array}{c}6.8 \\
(5.0-9.4)\end{array}$ & $\begin{array}{c}4.4 \\
(2.9-6.5)\end{array}$ & $<12.5$ & N/A \\
\hline
\end{tabular}

Data from Lors et al. (2011)

N/A not applicable. 
Table 3 Ecotoxicological characteristics of Soil B according to a restricted battery of solid and liquid bioassays

\begin{tabular}{|c|c|c|c|c|c|c|}
\hline & $\begin{array}{c}\mathrm{EC}_{50} \\
\left(\mathrm{g.} .100 \mathrm{~g}^{-1}\right)\end{array}$ & $\begin{array}{c}\text { TU } \\
100 / \mathrm{EC}_{50}\end{array}$ & $\begin{array}{c}\mathrm{EC}_{20} \\
\left(\mathrm{g.100} \mathrm{g}^{-1}\right)\end{array}$ & $\begin{array}{c}\mathrm{EC}_{10} \\
\left(\mathrm{g.100} \mathrm{g}^{-1}\right)\end{array}$ & $\begin{array}{c}\text { NOEC } \\
\left(\mathrm{g.100} \mathrm{g}^{-1}\right)\end{array}$ & $\begin{array}{c}\text { Inhibition } \\
(\%)\end{array}$ \\
\hline Lactuca germination & $>100$ & $<1$ & $\begin{array}{c}80.8 \\
(62.9->100)\end{array}$ & $\begin{array}{c}41.7 \\
(29.9-58.1)\end{array}$ & $<35$ & 21.4 \\
\hline $\begin{array}{l}\text { Folsomia population } \\
\text { growth }\end{array}$ & NT & NT & NT & NT & NT & 0 \\
\hline Folsomia avoidance & $>100$ & $<1$ & $\begin{array}{c}1.7 \\
(0.6-5.1)\end{array}$ & $\begin{array}{c}0.04 \\
(0.004-0.403)\end{array}$ & $<0.35$ & 12.5 \\
\hline Microtox $^{\circledR}$ test & NT & NT & NT & NT & NT & 0 \\
\hline Algal growth & $\begin{array}{c}80.5 \\
(51.7->100)\end{array}$ & 1.2 & $\begin{array}{c}8.4 \\
(5.3-13.5)\end{array}$ & $\begin{array}{c}2.6 \\
(1.2-5.7)\end{array}$ & $<6.25$ & 56.5 \\
\hline Micronucleus test (-S9) & $\mathrm{NM}$ & $\mathrm{NM}$ & NM & NM & $\mathrm{NM}$ & N/A \\
\hline
\end{tabular}

Data from Lors et al. (2011)

$N T$ not toxic, $N M$ not mutagenic, $N / A$ not applicable. 
Table 4 Ecoscores of the two studied soils calculated from the bioassay scores obtained with the battery of solid and liquid bioassays

Scores $(\%)$

\begin{tabular}{ccccc} 
& & & \multicolumn{2}{c}{ Scores (\%) } \\
& Bioassays & Effects & Soil A & Soil B \\
\hline \multirow{2}{*}{$\begin{array}{c}\text { Solid phase } \\
\text { bioassays }\end{array}$} & Folsomia population growth & Chronic ecotoxicity & 100 & 0 \\
& Folsomia avoidance & Behaviour & 100 & 67 \\
Solid phase bioassays battery & & $\mathbf{9 7 . 7}$ & $\mathbf{3 8 . 0}$ \\
Liquid phase & Vibrio fischeri inhibition & Acute ecotoxicity & 100 & 0 \\
bioassays & Pseudokirchneriella growth & Chronic ecotoxicity & 80 & 80 \\
& Micro-nucleus test & Genotoxicity & 80 & 0 \\
Solid and liquid & Liquid phase bioassays battery & & $\mathbf{8 6 . 7}$ & $\mathbf{2 6 . 7}$ \\
phase bioassays & Bioassays battery & & $\mathbf{9 2 . 2}$ & $\mathbf{3 2 . 3}$ \\
\hline
\end{tabular}

The values of ecoscores noted in bold type correspond to the average of bioassay-scores 
Table 5 Concentration of PAHs in water extracts A and B (expressed in $\mu \mathrm{g} \mathrm{L}^{-1}$ ) and water solubility of PAHs at $25^{\circ} \mathrm{C}$ (expressed in $\mu \mathrm{g} \mathrm{kg}^{-1}$ )

\begin{tabular}{|c|c|c|c|c|}
\hline & No. of rings & Water extract $A$ & Water extract B & Water-solubility \\
\hline Naphthalene & 2 & $0.20 \pm 0.02$ & $0.6 \pm 0.2$ & $3.210^{4}$ \\
\hline Acenaphthylene & 3 & - & - & $3.410^{3}$ \\
\hline Acenaphthene & 3 & $154.1 \pm 1.5$ & $0.6 \pm 0.1$ & $3.910^{3}$ \\
\hline Fluorene & 3 & $198.7 \pm 3.7$ & $0.7 \pm 0.1$ & $2.010^{3}$ \\
\hline Phenanthrene & 3 & $151.4 \pm 2.8$ & $1.4 \pm 0.2$ & $1.310^{3}$ \\
\hline Anthracene & 3 & $26.9 \pm 0.4$ & $1.3 \pm 0.3$ & $7.310^{1}$ \\
\hline Fluoranthene & 4 & $51.2 \pm 0.9$ & $4.1 \pm 0.7$ & $2.610^{2}$ \\
\hline Pyrene & 4 & $28.9 \pm 0.5$ & $3.1 \pm 0.6$ & $1.410^{2}$ \\
\hline Benzo[a]anthracene & 4 & $8.0 \pm 0.1$ & $3.1 \pm 0.6$ & $1.410^{1}$ \\
\hline Chrysene & 4 & $8.8 \pm 0.1$ & $3.4 \pm 0.6$ & $2.010^{0}$ \\
\hline Benzo[b]anthracene & 5 & $3.85 \pm 0.05$ & $8.4 \pm 1.4$ & $1.210^{0}$ \\
\hline Benzo[k]fluoranthene & 5 & $2.30 \pm 0.03$ & $2.7 \pm 0.5$ & $7.610^{-1}$ \\
\hline Benzo[a]pyrene & 5 & $4.41 \pm 0.02$ & $6.9 \pm 1.4$ & $3.810^{0}$ \\
\hline Dibenzo[ah]anthracene & 5 & $0.72 \pm 0.01$ & $3.4 \pm 0.6$ & $2.610^{-1}$ \\
\hline Benzo[ghi]perylene & & $3.00 \pm 0.03$ & $8.4 \pm 1.7$ & $6.210^{1}$ \\
\hline Indeno $[123-c d]$ pyrene & & $2.30 \pm 0.04$ & $9.0 \pm 1.8$ & $5.010^{-1}$ \\
\hline 2-ring PAH & & $0.20 \pm 0.02$ & $0.6 \pm 0.2$ & - \\
\hline 3-ring PAHs & & $531.1 \pm 8.3$ & $4.1 \pm 0.7$ & - \\
\hline 4-ring PAHs & & $96.9 \pm 1.7$ & $13.7 \pm 2.4$ & - \\
\hline 5-ring PAHs & & $11.3 \pm 0.1$ & $21.4 \pm 3.8$ & - \\
\hline 6-ring PAHs & & $5.30 \pm 0.05$ & $17.5 \pm 3.5$ & - \\
\hline$\sum 16$ PAHs & & $644.8 \pm 12.0$ & $57.3 \pm 11.2$ & - \\
\hline
\end{tabular}

Values are means of three replicate measures. Data from Lors et al. (2011) 


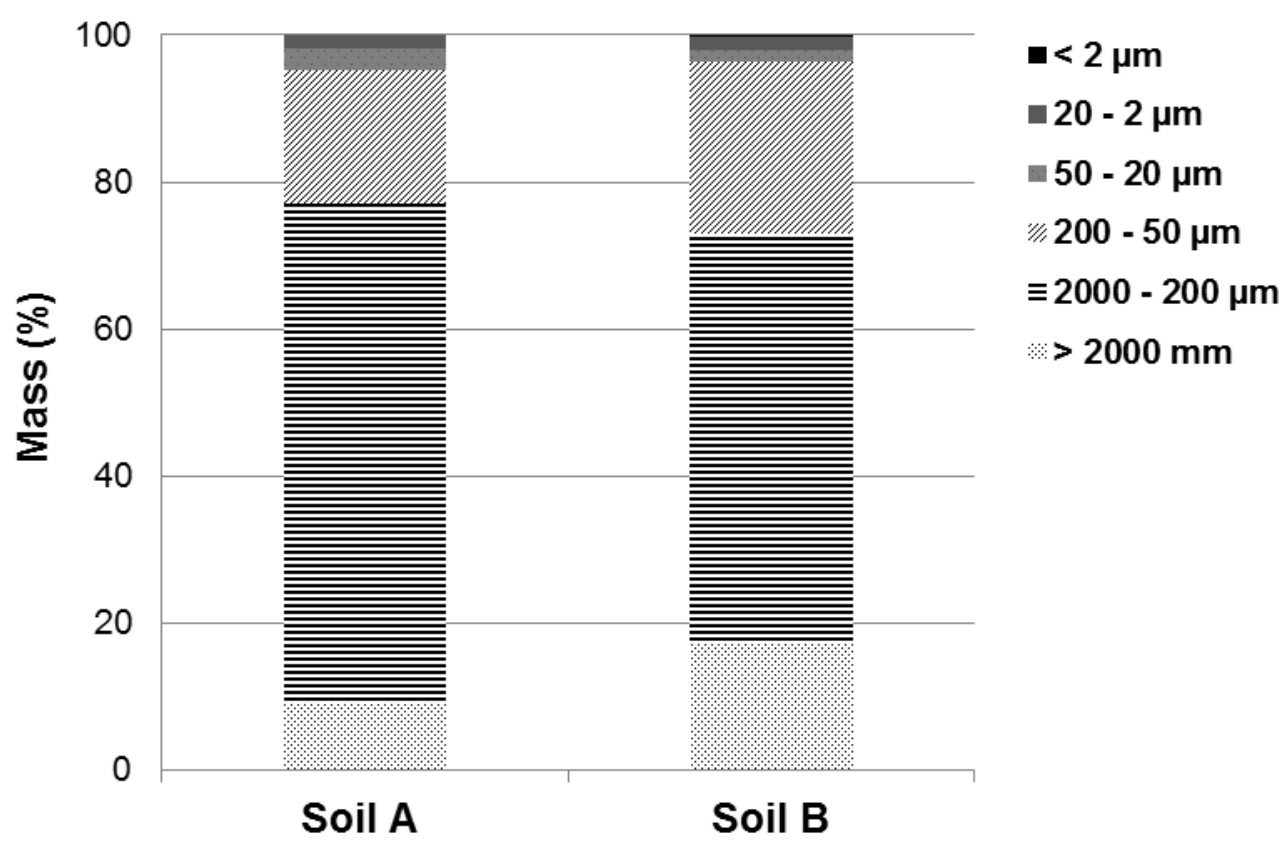

Fig. 1 


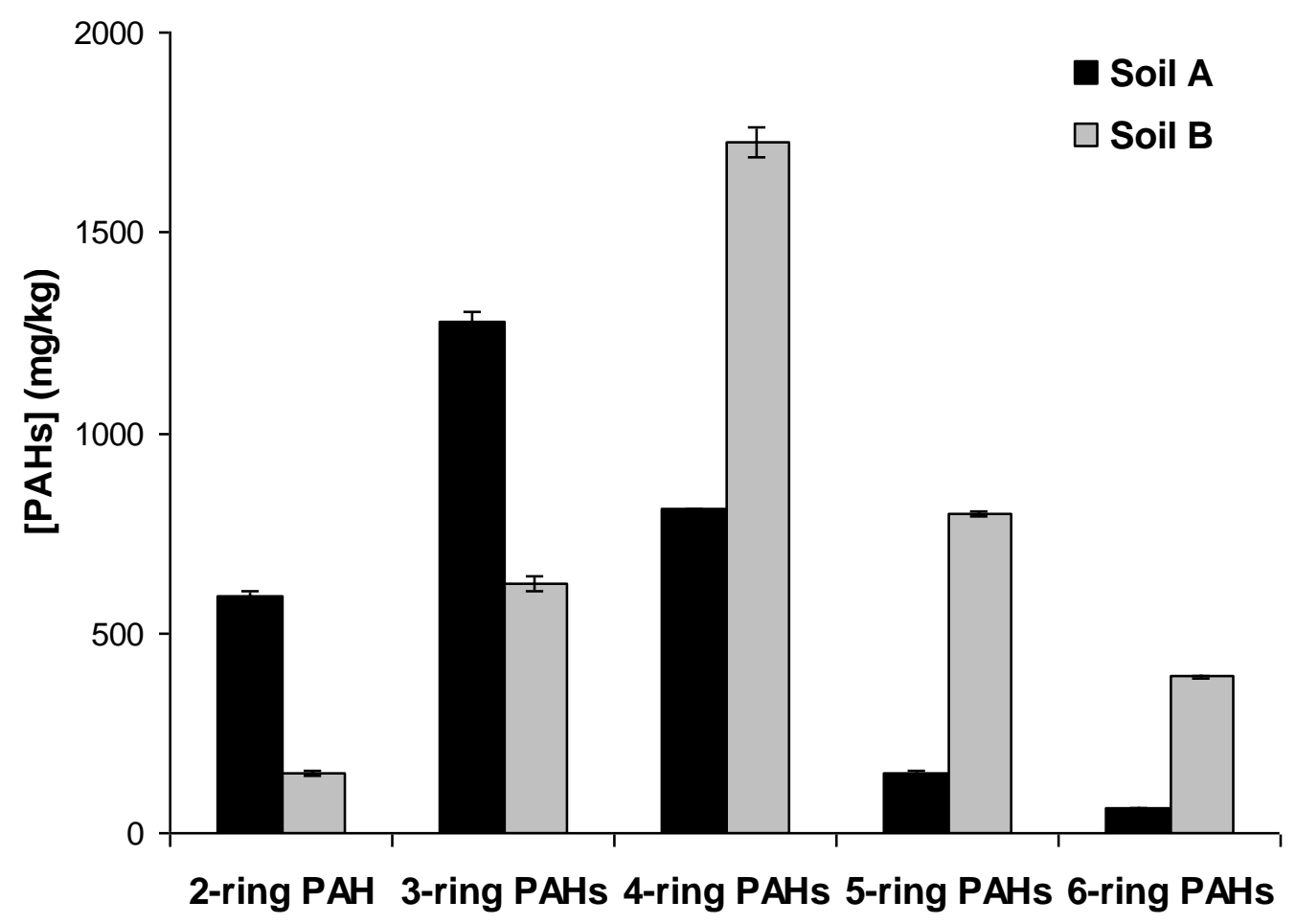

Fig. 2 


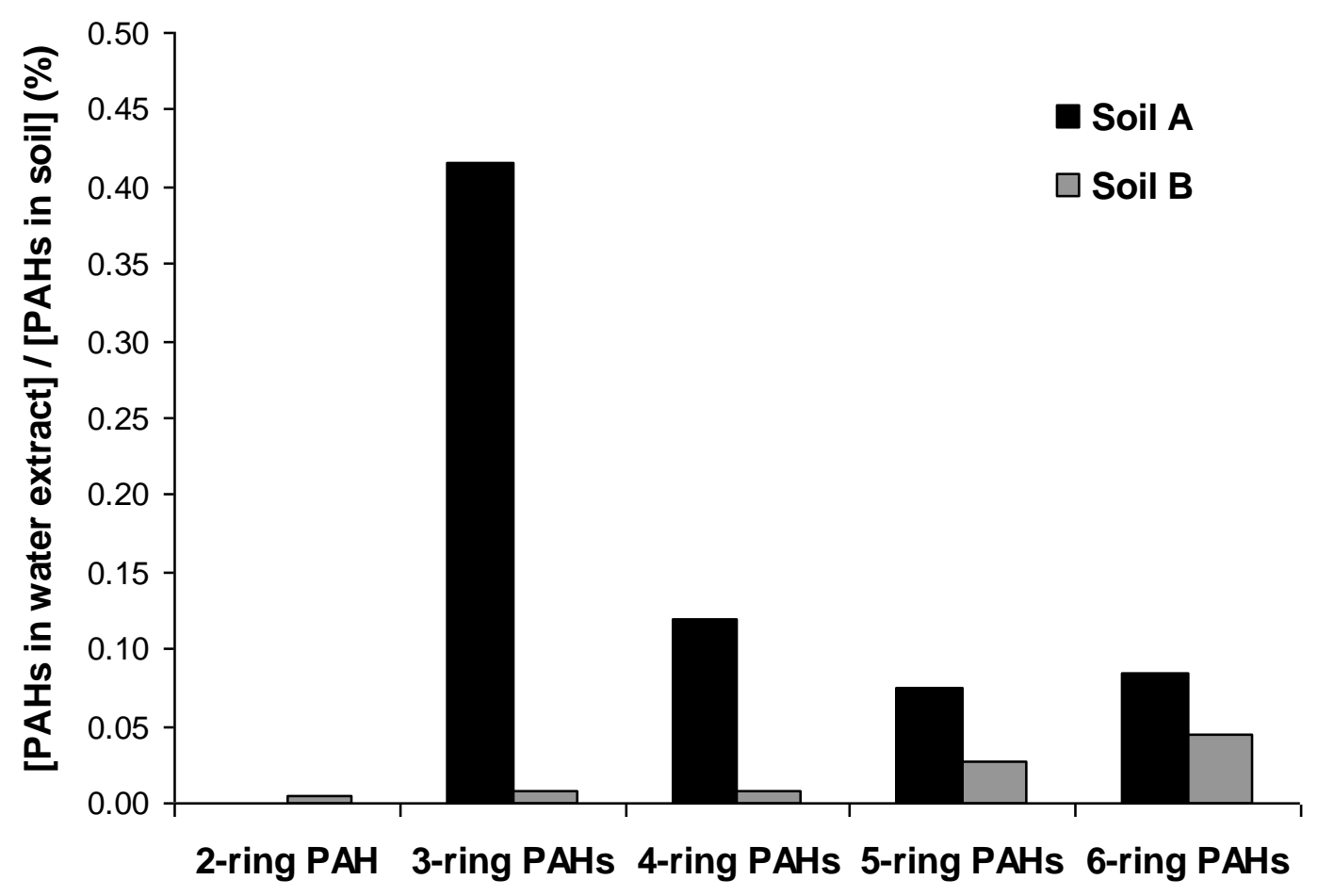

Fig. 3 